\title{
The Plastics Sunset and the Bio-Plastics Sunrise
}

\author{
Raffaele Porta $(\mathbb{D}$ \\ Department of Chemical Sciences, University of Naples "Federico II", Complesso Universitario di Monte \\ Sant'Angelo, via Cintia 21, 80126 Naples, Italy; raffaele.porta@unina.it
}

Received: 20 May 2019; Accepted: 7 August 2019; Published: 19 August 2019

\begin{abstract}
Plastics has been an integral part of our lives for the last century as the main material for various useful commodity items. Irony of fate, the same specific properties that make plastics ideal to create such a wide range of products are also responsible for the present dramatic environmental pollution. What suggestions do the technological innovations currently suggest to solve this worldwide problem? Among the others, one is to replace the traditional plastics with alternative materials derived from non-oil polymers capable of being degraded in months and not in years or centuries. But the research in this field is relatively new and undoubtedly there are still developments that need to be made. Thus, we must be aware that the plastic age is at sunset and the bio-plastics sun is just rising on the horizon.
\end{abstract}

Keywords: plastics; bio-plastics; biopolymers; biodegradable materials; environmental pollution

\section{Introduction}

Nowadays "bio" is one of the most used codes in the international dictionary. It is increasingly often added to the beginning of different words to characterize disciplines, events, or products as extraordinarily useful, beneficial, and even healthy novelties. Often rightly, sometimes even wrongly when the term bio is used for misleading purposes, as in so-called "bio-dynamic agriculture" toward which the majority of researchers remain skeptical arguing that this discipline was not developed through scientific methodology but only through mysticism. In fact, the biodynamic methods cannot be tested and validated and no evidence exists to prove that this system of agricultural management determines plant or soil quality improvements [1]. In any case, it is not enough to define something as "biological" for turning it into beneficial and healthy.

This terminology also includes the bio-plastics [2,3]; innovative materials that have the ambition to replace another material, the plastics, which progressively invaded the environment around us since the Second World War and are involved almost everywhere in the lives of human beings: the houses we live in, the places where we work, the transportation means we use, almost every tools and objects we utilize, and even the clothes we usually wear.

If we look around, in fact, we can easily realize that it is not an exaggeration to say that, for over a century, present time can be defined as "the plastics age" as for our ancestors it has been the age of stone, bronze, or iron.

\section{Plastics Revolution and Pollution}

The beginnings of this new era can be dated in the mid-19th century with the discovery of the nitrocellulose by Christian Schönbein who, mixing cotton, nitric acid, and sulfuric acid together, succeeded in obtaining the guncotton, a material that first proved to be very dangerous as it was easily flammable and even explosive, but about 30 years later, added with camphor and marketed under the name of celluloid, it made possible the birth of the cinematography. In 1883 Hilare Bernigaud de Chardonnet developed a semi-synthetic fiber named viscose, an "artificial silk" better known since 
1924 as rayon, from cellulose by dissolving cellulose in aqueous sodium hydroxide in the presence of carbon disulfide; whereas in 1908 a different treatment of the same colloidal solution made by Jacques Brandenberger gave rise to the well-known packaging film named cellophane.

Then, in 1907, Leo Baekeland invented the bakelite, the first fully synthetic plastic polymer, by reacting phenol and formaldehyde at controlled temperatures and pressure. The bakelite, known as being the fundamental component of the materials, making up the first generation phones, representing the today desire of modern items collectors, was widely used for producing numerous household appliances and, unfortunately, the main weapons used during the Second World War. Then appeared the PVC (polyvinyl chloride), which replaced the metals in the production of waterproof pipes, electrical cables, and flooring, and shortly afterward, both polystyrene and nylon, patented by "Dow Chemical" and "Dupont" used for new packaging and fibers textiles. But it was only in the second half of the 20th century that a real "plastics revolution" began, after that Rex Whinfield and James Tennant Dickson in 1941 patented PET (polyethylene terephthalate) and when Karl Ziegler refined two years after the ethylene polymerization. At first PET had a great success in the production of "tertial" a cloth better known today as "pile" but then it gave origin to the plastic bottles. However, the entry of PET into the world of food packaging goes back to 1973, when Nathaniel Wyeth patented the first bottle used as a container for soft drinks. The second part of the past century saw the discovery of the melamine-formaldehyde, which replaced wood as the material for school desks, and of the isotactic polypropylene, whose paternity is by an Italian, Giulio Natta, who together with the Karl Ziegler a German, won the Nobel Prize in 1963 for such a discovery. Polypropylene was produced industrially with the "Moplen" brand, and then entered into the mythology of the Italian "economic boom" during the 1960s. Figure 1 shows the repeating units of all the mentioned polymers.

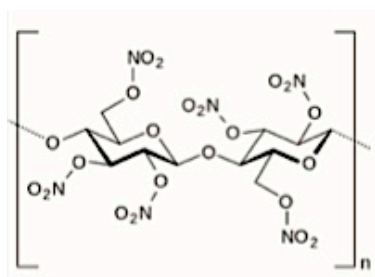

Nitrocellulose

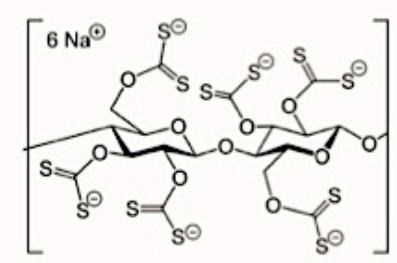

Viscosa/Rayon/Cellophane

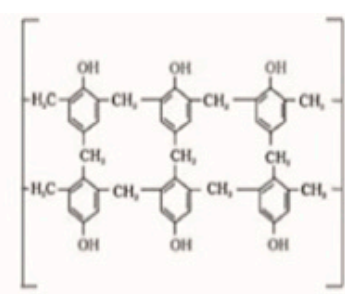

Bakelite

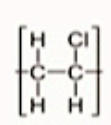

PolyVinyIChloride (PVC)<smiles>CCCCCCCCCCCCCCCCCCCCCC</smiles>

Polyethylene

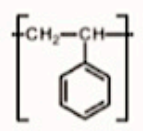

Polystyrene<smiles>CCCCCCCC(C)C</smiles>

Nylon 6

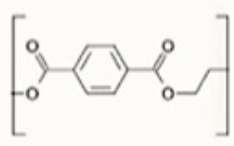

PolyEthylene Terephtalate (PET)

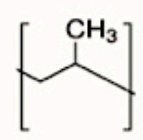

Polypropylene

Figure 1. Repeating units of the most representative plastic polymers.

The following decades were those of the progressive development of plastic materials in increasingly sophisticated and previously unpredictable applications owing to the so-called techno-polymers that, because of their characteristics of both thermal and mechanical resistance, proved to be often superior to the special metals. Techno-polymers, mainly thermoplastics, have a crystalline or amorphous structure and can become transparent when stretched. Today, they find 
application in every segment and expression of our life, such as the soundproofing of our house walls, the super-light tennis rackets, the contact lenses, the ski windbreakers, and even the bulletproof vests.

The use of plastics derived from petrochemical polymers have increased about 20 times in the last 50 years. Only in the European countries, over 1.5 million people are working at the moment in over 60 thousand companies producing an annual turnover of around 400 billion euros [4]. This sector includes not only the producers but also the transformers of plastics and the industries manufacturing highly sophisticated machinery fitted to mold plastics for different uses. It is one of the most cutting-edge sectors in the European Union, being responsible for $4 \%$ of the total patents filed annually. Therefore, when we demand a "plastic free" world, we must know that it is necessary to take these data into due consideration, even though it is now universally recognized that it is essential to progressively decrease the production of the oil-derived plastics. In fact, as always, "not all that glitters is gold," and plastics show a second face of the coin: besides being a material of exceptional versatility, they represent the savage face of a devastating environmental pollution.

Since the beginning of plastics revolution, it was estimated that over 6 billion tons of plastic waste have been produced worldwide [5]. Less than $10 \%$ of the 300 million tons of plastic wastes produced every year in the world is recycled, while the remaining ends up in landfills and oceans giving rise, over time, to more and more small and toxic petro-polymers, which are ingested by marine animals and zooplankton [6-8]. It has been estimated that over 5 trillion plastic particles weighing about 300 thousand tons float on the surface of the oceans and release various toxic substances, including "bisphenol" [9]. These micro-plastics kill more than 100,000 marine mammals each year, as well as millions of birds and fish. It was reported that about one million and a half of the albatrosses that inhabit the Midway Islands have plastic in their digestive system [9]. The subtropical seawaters between California and the Hawaiian Islands are today the main accumulation areas of the oceanic plastic, known as GPGP (Great Pacific Garbage Patch), consisting of over 80 thousand tons floating plastic waste, such a garbage island that covers about 1.6 million $\mathrm{km}^{2}$ and has a surface three times larger than France [10]. Furthermore, only $26 \%$ of the about 50 million tons of plastic used annually in the 27 countries of the EU is recycled, while $38 \%$ of the plastic wastes is deposited in landfills and $36 \%$ destroyed by combustion [4].

\section{The Ways Forward: Key Challenges and Strategies}

Hence, which solutions does the world of technological innovations offer today to counteract the pollution because of the various types of traditional plastics? At the moment, research is moving in three different directions (Figure 2).

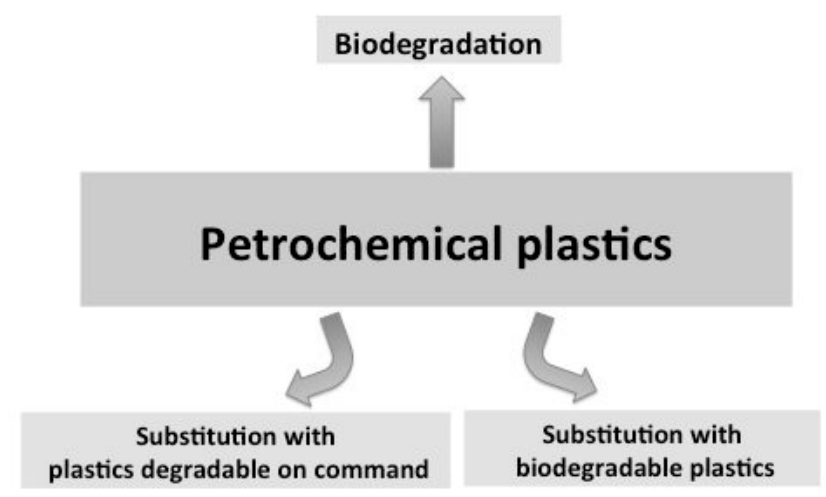

Figure 2. Possible strategies to counteract petrochemical plastics pollution.

The first way is aimed at selecting living organisms capable to use plastics as nourishment by decomposing polymers into small molecules which are then assimilated and enters into their metabolic chain. An example is represented by Ideonella sakaiensis 201-F6, a bacterium from the Comamonadaceae family, which is able to digest and assimilate PET by two enzymatic reactions 
(Figure 3) [11]. The discovery of this bacterium took place in Japan during a systematic research on colonies of microorganisms present in hundreds of samples extracted from PET-containing wastes long been present in different landfills. Since PET has been present on our planet for less than a century, it is amazing that a microorganism may have evolved in such a very short time becoming capable to feed on such a polymer. More recently, mutated forms of enzymes involved in PET biodegradation, endowed with a greater efficiency than the native ones present in Ideonella sakaiensis, have also been engineered [12].

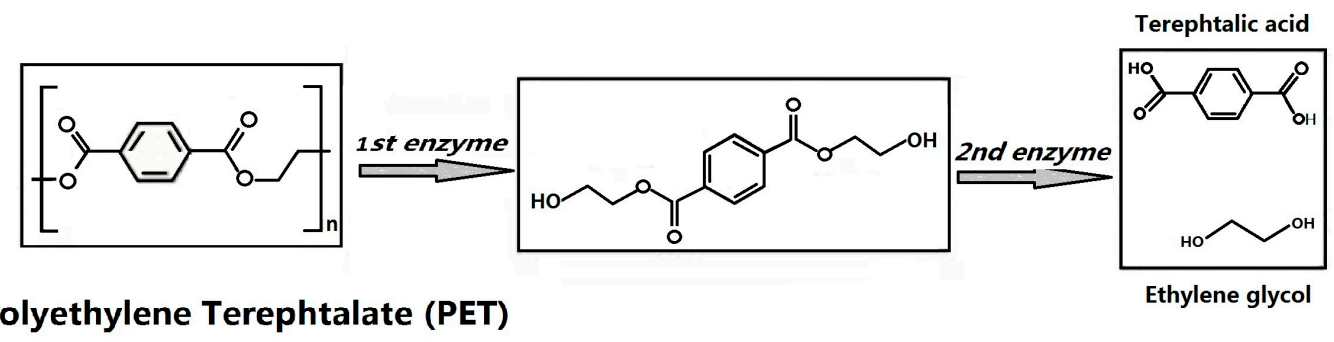

Figure 3. Polyethylene tetraphtalate biodegradation by Ileonella sakaiensis 201-F6.

Even the larvae of the wax moth Galleria mellonella, the common honey camola well-known to the fishermen who use it as bait, has proved to be capable of degrading polyethylene [13]. The discovery occurred by a group of researchers in Spain and UK when they noticed that some plastic bags containing these larvae were full of holes. After calculating that $13 \%$ of the plastics from which the bags were made had been disintegrated in less than $14 \mathrm{~h}$, they checked whether the caterpillar had ingested such kind of plastics as such or if it had managed to biodegrade it. They discovered, thus, that polyethylene was chemically transformed into ethylene glycol, the same organic compound produced by PET biodegradation and that we use routinely as antifreeze for our cars. In brief, being able to digest the beeswax they normally eat, these caterpillars have developed, in the presence of polyethylene, the ability to break further chemical bonds as well. However, will Ideonella sakaiensis and/or Galleria mellonella be able to degrade huge amounts of polymer waste? Won't there be any drawbacks if these organisms will be used at a very large scale? A solution could be to isolate and immobilize the enzymes responsible for polymer degradation by manufacturing specific bioreactors.

The second strategy involves the commitment to create new plastic materials capable of restoring on demand the monomers of origin [14]. The plastics we know, in fact, are not designed to disintegrate. Conversely, they are meant for lasting as long as possible. The dramatic environmental effects caused by the accumulation of plastics have, thus, stimulated researchers to find out new materials with two apparently conflicting requirements: they must be durable, but even easily degradable to our liking under certain stimuli, i.e., they must be endowed with a built-in self-destruct mechanism. The trick would be to make the polymer materials stable when they are used and unstable when we require to disintegrate them. For better understanding this strategy, it is as if a house could easily be brought back, at the end of its function, into its original bricks, which in turn can be used to build a new construction for different purposes, such as a factory or a bridge. The dismantling of these materials is technically called "decompression", because once the mechanism that makes the polymer fragile is triggered, the single monomer units would detach one after the other until the material is completely disintegrated. The starting point of this approach is paradoxically leading to the re-evaluation of polymers known to be intrinsically unstable and historically neglected precisely because of their inherent fragility. However, the monomeric units must be safe and non-toxic. Among various potential candidates, the attention is currently focused on glyoxylate, a molecule widely found in nature, especially in numerous soil microorganisms. Polyglyoxylates represent a recently introduced class of self-immolating polymers, capable to depolymerize upon the cleavage of a stimuli-responsive end-cap from the polymer terminus, with promising properties for applications as coatings, sensors, tissue engineering, and drug delivery. 
These new materials are particularly attractive as the component monomers can be derived not only from petroleum-based sources, but also from renewable resources $[15,16]$.

With both strategies described so far, however, the aim is to degrade the plastic polymers obtained by chemical synthesis in a relatively short time, weeks or months, so that no more damage to the planet or to the organisms living on it is caused; whereas the different types of conventional plastics take decades or even centuries to disintegrate into simple molecules.

A third possibility to counteract such a dramatic pollution is to replace at least part of the conventional plastics with new materials derived from non-oil macromolecules that are biodegraded in shorter times than the nature takes to destroy plastic materials by chemical-physical means $[17,18]$. These are the bioplastics, innovative materials obtained from renewable organic sources, possibly derived from wastes, or in any case by low cost by-products, which can be enzymatically digested by specific living organisms present in the soil and/or in the sea. Recently, on "World Environment Day", Nature Communications asks in the editorial: "will biodegradable polymers alleviate plastic's environmental impact?" [19]. The production of the various bioplastics, even though in strong growth (it is expected a production in 2025 of over 6 million tons only in the European Union countries), does not exceed $3 \%$ of the total traditional plastics at the moment, as their mechanical and permeability features, as well as the relative production costs (2-4 times higher than those of conventional plastics) are still unacceptable for the market. In fact, the items made of traditional plastics are light, moldable, waterproof, transparent or colored, hard or flexible as desired, and the consumers require that biodegradable plastics should possess all or at least most of such properties.

European Union is the leader with $55 \%$ of the global market for the bio-plastic consumption in 2018, followed by Asia/Oceania with 25\% and North America with 19\%. The main producers of biodegradable polymers are currently NatureWorks (a joint venture of Cargill and PTT Global Chemical), Novamont, BASF and PTT-MCC Biochem Co. (a joint venture of PTT Public Company and Mitsubishi Chemical Corporation). Furthermore, TOTAL Corbion PLA (a joint venture of the TOTAL and Corbion Lactic Acid) plans to start by 2019 a plant for the world-scale production of lactic acid polymer in Thailand [20].

Packaging remains at the moment the widest field of application for bio-plastics, with around $50 \%$ of the market dedicated to it (the transport and the construction sectors cover $14 \%$ and $13 \%$, respectively, whereas other consumer goods cover 23\%) [21]. Bio-plastics specifically used in the food industry may have different characteristics. Beyond biodegradability, their potential to be compostable is extremely important, since not all bio-plastics are easily reduced to a mixture of humified substances, produced during an aerobic and controlled degradation process operated by bacteria and fungi, which can be exploited for agronomic purposes as well as for increasing the biodiversity of the micro-flora. Further attractive features of biodegradable materials destined for food coating are their edibility and digestibility. In fact, bio-plastics are edible but not digestible, since the possibility of their safe ingestion does not necessarily entail the possibility that the organism digests, absorbs, and/or assimilates them.

The matrix components originating the current biodegradable plastics may be divided into three main categories: polylactic acid (PLA), polyhydroxyalkanoates (PHAs), and the natural thermoplastic biomacromolecules [22-25] (Figure 4).

PLA is cheap to produce (generally from lactic acid by biomass fermentation) but slow to be degraded. Although it has poor impact resistance and limited barrier and thermal properties, PLA currently represents over a fifth of the overall bio-plastics market, mainly giving rise to prostheses and medical/health facilities as well as various types of packaging. Conversely, there are over 150 different PHAs, which make up many types of material capable to easily biodegrade in water. However, even though they have great potential, so that their market extent is destined to grow considerably in the near future, they still are quite expensive at the moment to be produced. Finally, some naturally occurring macromolecules-first among these starch-were mixed with plasticizers to produce thermoplastic biopolymers [26,27]. They make up today almost half of the biodegradable plastics of the global market and are mainly used to produce bags (70\%) and other types of packaging. Even cellulose, 
the most abundant polysaccharide in nature, has the ability to become thermoplastic if chemically modified. An example is represented by the cellulose acetate, which, however, still contemplates high production costs. Moreover, cellulosic fibers when added to starch made the material less hydrophilic and significantly improved its mechanical and gas permeability properties [28].

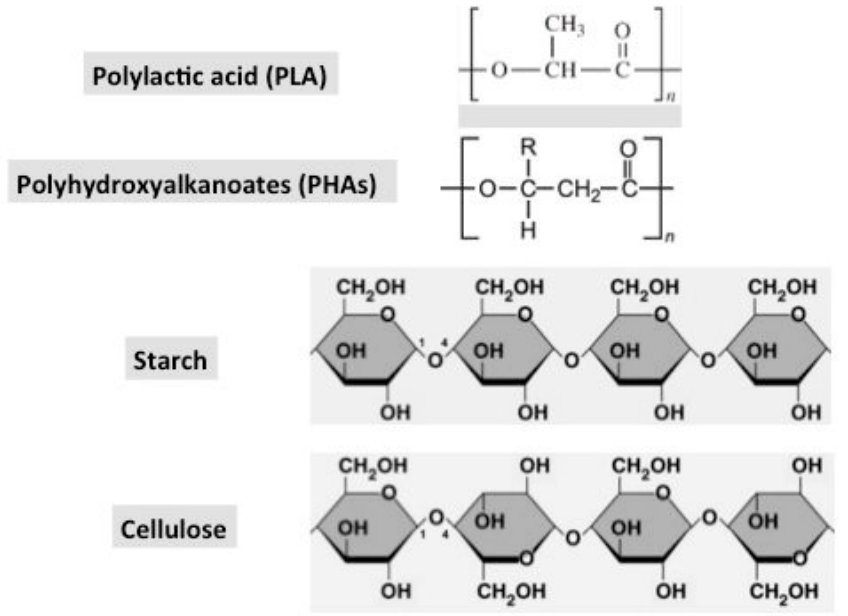

Figure 4. Main biopolymers currently used as bioplastics matrices.

Although PLA and starch remain at the moment the main polymeric sources used in the production of biodegradable plastics, the main challenge is to identify new raw materials capable of giving rise, through innovative transformation processes, to bio-plastics that are able to compete more effectively with the traditional plastics mainly in coating or wrapping the most varied kinds of food (fruits and vegetables, as well as meat, fish, and dairy products). New materials suitable for this purpose might be obtained from proteins of different origin, both plant and animal. In fact, proteins extracted from wheat and from the seeds of leguminous plants, as well as those contained in milk [29], show film forming properties which makes them potential biopolymer candidates for new biodegradable materials intended for the market. Because of their multi-monomeric chains, proteins are different from synthetic polymers made up of a single repeating unit and may give rise to different interactions (electrostatic, dipolar, hydrophobic and hydrogen bonding) depending on their specific amino acid composition and sequence. Extended structures derived from protein unfolding (by heating and/or by changing the $\mathrm{pH}$ and/or by adding various chemical agents), as well as the addition of low molecular weight compounds that is able to lower the glass transition temperature (e.g., glycerol and sorbitol), is generally required for film formation. However, application of proteins to the material science is not a recent achievement but dates back to the 1850s, when composite material of saw dust and blood were used to make plaques. Further commercialized products were obtained from casein proteins in the early 1900s and then, in the 1930s, Henry Ford filed a patent for a soy protein-based bioplastic hardened with formaldehyde for use as car body panels [30].

Nevertheless, the attention of many researchers was recently quite focused on possible raw materials to be obtained at very low costs and, in particular on biopolymers contained in organic wastes, as well as in several industrial by-products, for their possible recovery, recycling, and reuse to realize a virtuous circular economy trial [31]. The second characterizing aspect of the current research in this sector is represented by innovative processes of transformation of the single biopolymers, in order to improve their mechanical properties, permeability, and to engineer the single bio-plastics for the specific uses to which they should be destined. These processes include the use of the modern nanotechnologies, the chemical or enzymatic formation of intermolecular cross-links, and the grafting of the polymeric matrices with various types of additives (i.e., plasticizing, structuring, antimicrobial, antioxidant and flavoring agents) that can give rise to "active and intelligent" food packaging materials $[32,33]$. 


\section{Current and Future Perspectives}

Although bio-plastics are generally considered an eco-friendly alternative to the traditional plastics owing to the renewable feedstock used, the farming practices used to grow them often produce significant environmental impacts, and the necessary energy can be sometime even higher than that needed to obtain conventional plastics. On the other hand, the "life cycle assessments" of biopolymers, compared to those of petrochemical polymers, did not attain to definitive results, because most studies have been focused only on the global warming potential and not on other environmental impact parameters. Therefore, this aspect deserves to be taken into serious account for future optimization of the technologies producing bio-plastics and to improve the efficiency of the related processes [34].

However, the time of scientific research is unpredictable, and often not compatible with the social emergencies, whereas the planetary pollution requires urgent interventions. Although plastics are recognized as a hazardous waste by the major governmental organizations, as indicated in some international regulations and conventions such as the "International Convention for the Prevention of Marine Pollution" (Marpol), controls in most countries are certainly not yet adapted to the current emergency. The European Union Parliament recently decided to strengthen the Commission's plans to reduce plastics pollution, stating with a resolution that at the moment "biodegradable and compostable plastics are not able to prevent plastic pollution and should not be an alibi to continue to consume single-use plastic materials." However, the most recent European Union directives foresee only the adoption of new rules on single-use plastics to reduce marine litter by 2021, the prohibition of using micro-plastics in detergents, cosmetics, and in all personal care products by 2020, as well as the reduction of dangerous substances in plastic materials to ensure that the recycled plastics are partially free of harmful chemicals. Unfortunately, the European Parliament did not take any measure yet to hinder the diffuse pollution caused by the so-called "nurdles" - small pellets normally between 1 and $5 \mathrm{~mm}$, colored and round shaped easily mistaken for fish eggs and small prey in the seawater-used to manufacture the countless plastic items for daily use. Furthermore, it did not yet provide any strong economic incentive to reduce the production and consumption of conventional plastics. Perhaps bio-plastics do not yet represent at the moment the solution to the pollution caused by plastics; but certainly the "mountain" of the European Union Parliament has given birth once again only to a little "mouse."

Funding: This research was funded by the grant PRIN: Progetti di Ricerca di Interesse Nazionale -Bando 2017- “CARDoon valorisation by InteGrAted biorefiNery (CARDIGAN)" of italian Ministero dell'Istruzione dell'Università e della Ricerca (COD. 2017KBTK93).

Conflicts of Interest: The authors declare no conflict of interest.

\section{References}

1. Ruse, M. Evolution: From pseudoscience to popular science, from popular science to professional science. In Philosophy of Pseudoscience: Reconsidering the Demarcation Problem; Pigliucci, M., Boudry, M., Eds.; University of Chicago Press: Chicago, IL, USA, 2013; p. 227.

2. Prata, J.C.; Patricio Silva, A.L.; da Costa, J.P.; Mouneyrac, C.; Walker, T.R.; Duarte, A.C.; Rocha-Santos, T. Solutions and integrated strategies for the control and mitigation of plastic and microplastic pollution. Int. J. Environ. Res. Public Health 2019, 16, 2411. [CrossRef] [PubMed]

3. Yang, J.; Ching, Y.C.; Chuah, C.H. Applications of lignocellulosic fibers and lignin in bioplastics: A review. Polymers 2019, 11, 751. [CrossRef] [PubMed]

4. Plastics Europe Annual Review 2017-2018. Available online: www.plasticseurope.org (accessed on 10 May 2019).

5. The New Plastics Economy: Rethinking the Future of Plastics. Available online: www. ellenmacarthurfoundation.org/publications/the-new-plastics-economy-rethinking-the-future-of-plastics (accessed on 10 May 2019).

6. UNEP-UN Environment. Available online: web.unep.org (accessed on 10 May 2019).

7. Plastic Oceans. Available online: www.plasticoceans.org (accessed on 10 May 2019). 
8. Geyer, R.; Jambeck, J.R.; Lavender Law, K. Production, use, and fate of all plastics ever made. Sci. Adv. 2017, 3, e1700782. [CrossRef] [PubMed]

9. $\quad$ Eriksen, M.; Lebreton, L.C.M.; Carson, H.S.; Thiel, M.; Moore, C.J.; Borerro, J.C.; Galgani, F.; Ryan, P.J.; Reisser, J. Plastic pollution in the world's oceans: More than 5 trillion plastic pieces weighing over 250,000 tons sfloat at sea. PLoS ONE 2014, 9, e111913. [CrossRef] [PubMed]

10. Guern, C.L. When the Mermaids Cry: The Great Plastic Tide. Available online: www.plastic-pollution.org (accessed on 10 May 2019).

11. Yoshida, S.; Hiraga, K.; Takehana, T.; Taniguchi, I.; Yamaji, H.; Maeda, Y.; Toyohara, K.; Miyamoto, K.; Kimura, Y.; Oda, K. A bacterium that degrades and assimilates poly(ethylene terephthalate). Science 2016, 351, 1196-1199. [CrossRef]

12. Austin, H.P.; Allen, M.D.; Donohoe, B.S.; Rorrer, N.A.; Kearns, F.L.; Silveira, R.L.; Pollard, B.C.; Dominick, G.; Duman, R.; El Omari, K.; et al. Characterization and engineering of a plastic-degrading aromatic polyesterase. Proc. Natl. Acad. Sci. USA 2018, 115, E4350-E4357. [CrossRef]

13. Bombelli, P.; Howe, C.J.; Bertocchini, F. Polyethylene bio-degradation by caterpillars of the wax moth Galleria mellonella. Curr. Biol. 2017, 8, R292-R293. [CrossRef]

14. Zhang, Z.P.; Rong, M.Z.; Zang, M.Q. Polymer engineering based on reversible covalent chemistry: A promising innovative pathway towards new materials and new functionalities. Prog. Polym. Sci. 2018, 80, 39-93. [CrossRef]

15. Fan, B.; Trant, J.F.; Wong, A.D.; Gillies, E.R. Polyglyoxylates: A versatile class of triggerable self-immolative polymers from readily accessible monomers. J. Am. Chem. Soc. 2014, 136, 10116-10123. [CrossRef]

16. Kenaree, A.R.; Gillies, E.R. Polymerization of ethyl glyoxylate using alkyllithium and alkoxide initiators. Macromolecules 2018, 51,5501-5510. [CrossRef]

17. European Bioplastics. Available online: www.european-bioplastics.org (accessed on 10 may 2019).

18. Chen, G.-Q.; Patel, M.K. Plastics derived from biological sources: Present and future. A technical and environmental review. Chem. Rev. 2012, 112, 2082-2099. [CrossRef]

19. Editorial. The future of plastic. Nat. Commun. 2018, 9, 2157-2159. [CrossRef]

20. Biodegradable Polymers Market Forecast to Rise Sharply by 2023. Available online: www.bioplasticsmagazine.com/en/news/meldungen/2018-July-27-Biodegrable-plastics-market-forcast-torise-sharply-by-2023.php (accessed on 10 May 2019).

21. European Bioplastics. Applications for Bioplastics. Available online: www.european-bioplastics.org/market/ applications-sectors/ (accessed on 10 May 2019).

22. Nagarajan, V.; Mohanty, A.K.; Misra, M. Perspective on polylactic acid (PLA) based sustainable materials for durable applications: Focus on toughness and heat resistance. ACS Sustain. Chem. Eng. 2016, 4, 2899-2916. [CrossRef]

23. Murariu, M.; Dubois, P. PLA composites: From production to properties. Adv. Drug Deliv. Rev. 2016, 107, 17-46. [CrossRef]

24. Kourmentza, C.; Plácido, J.; Venetsaneas, N.; Burniol-Figols, A.; Varrone, C.; Gavala, H.N.; Reis, M.A.M. Recent advances and challenges towards sustainable polyhydroxyalkanoate (PHA) production. Bioengineering 2017, 4, 55. [CrossRef]

25. Vieira, M.G.A.; da Silva, M.A.; Beppu, M.M. Natural-based plasticizers and biopolymer films: A review. Eur. Polym. J. 2011, 47, 254-263. [CrossRef]

26. Han, J.H. (Ed.) Innovations in Food Packaging, 2nd ed.; Academic Press: Cambridge, MA, USA, 2014; pp. 1-624.

27. Teramoto, Y. Functional thermoplastic materials from derivatives of cellulose and related structural polysaccharides. Molecules 2015, 20, 5487-5527. [CrossRef]

28. Pérez-Pacheco, E.; Canto-Pinto, J.C.; Moo-Huchin, V.M.; Estrada-Mota, I.A.; Estrada-León, R.J.; Chel-Guerrero, L. Thermoplastic starch (TPS)-cellulosic fibers composites: Mechanical properties and water vapor barrier: A review. In Composites from Renewable and Sustainable Materials; Poletto, M., Ed.; IntechOpen: London, UK, 2016. [CrossRef]

29. Abdalrazeq, M.; Giosafatto, C.V.L.; Esposito, M.; Fenderico, M.; Di Pierro, P.; Porta, R. Glycerol-plasticized films obtained from whey proteins denatured at alkaline $\mathrm{pH}$. Coatings 2019, 9, 322. [CrossRef]

30. Ferreira, M.S.L.; Linhares, R.; Martelli, M. Films and coatings from agro-industrial residues. In Edible Films and Coatings Fundamentals and Applications; Pilar Monter, M., Carmen Gomez-Guillén, M., Elvira López-Caballero, M., Barbosa-Cánovas, G.V., Eds.; CRC Press: Boca Raton, FL, USA, 2016; pp. 193-214. 
31. Ralston, B.E.; Osswald, T.A. The history of tomorrow's materials: Protein-based biopolymers. Plast. Eng. 2008, 64, 36-40. [CrossRef]

32. Muller, P.; Schmid, M. Intelligent packaging in the food sector: A brief overview. Foods 2019, 8, 16. [CrossRef]

33. Porta, R.; Di Pierro, P.; Sabbah, M. Special Issue on “Biopolymers as Food Packaging Materials". Int. J. Mol. Sci. 2019, in press.

34. Yates, M.R.; Barlow, C.Y. Life cycle assessments of biodegradable, commercial biopolymers-A critical review. Resour. Conserv. Recycl. 2013, 78, 54-66. [CrossRef]

(C) 2019 by the author. Licensee MDPI, Basel, Switzerland. This article is an open access article distributed under the terms and conditions of the Creative Commons Attribution (CC BY) license (http://creativecommons.org/licenses/by/4.0/). 